\title{
Sustainable Agriculture and Farmers Choices Among Short Term Efficiency and Preserving the Future
}

\author{
Alda Miftari, PhD Candidate \\ Sapienza University of Rome, Italy
}

\section{Abstract}

This paper focuses the attention on the biodiversity of production system of farmers and the social impact in the environment process related on the economy scale. Farmers in Italian regions are growing fast and are developing new paradigms on sustainable agriculture for the development and eco-friendly products for the future of farming. The organic agriculture is an alternative of farming for producing in sustainable way and ensuring social and local conditions and promoting high level of food quality. On behalf of CAP reform 2020 and the Sustainable Development Goals, Agriculture is one of the pointed and discussed sectors concerning the preservation of environment and the welfare for the future generations. This article will focus the evaluation of the three pilasters of sustainability and the principles of organic agriculture. The methodology of this research is a quantitative model on using data from ISTAT, EUROSTAT database and statistical analysis are employed in this research. Our analysis shows the connection of new paradigms, methods and estimations on the sustainable development with the organic agriculture and discuss the farmers alternative for more sustainable agriculture development and revenue.

Keywords: environment; sustainable agriculture; organic agriculture; farms alternative.

\section{Theoretical framework}

Sustainable agriculture is one of the main topics of Sustainable Development Goals. The differences from organic agriculture, agroecological agriculture and conventional agriculture will be discussed in this paper. The agriculture is the major water-use and conservation sector in the European Union (EU), with a very high use ranging from 40 to $80 \%$ of total water usage for agriculture activities in the main EU countries (Stolze, Piorr, Haring, \& Dabbert, 2000). In the past, urban water resources management were considered problematics for the cities about the hygienic problems implied. The process of development, globalisation and industrialization, has undergone major changes in urban and agriculture sustainable management. The main linkages between sustainable agriculture management and policies regarding adaptation strategies for a sustainable water use together with knowledge and the presence of farmers participation has been discussed in the previous paper of (Miftari, 2019). Farmers are the main actors and they have a big responsibility on conservation, management and protection of environment and biodiversity. In this paper we have analyse the agricultural land price for all 20 Italian regions and the average of organic farming land 
available in Italy from 2012 to 2017 (EUROSTAT, 2018). This article will mainly deal with determination of organic farming with all the aspects and the effects in biodiversity, ecosystem and society. It' reliefs the relation with environment and combines to the social cultural traditions. Through Social Sciences and especially from Sociological studies we will assess this process of transformation in a vertical way which is linked with society. Overall the association between production, food security and consumption are directly interrelated with the evolution of agro-food-systems, as it is discussed within the "production-consumption debate" (Lockie, 2002). Social and biological agriculture scientist contributes to the enlargement of the concept of human rights to be extended to include such things as social, environmental and climatic change. This influence has led within the consumption of production directly by the civil society. Other contribution has been done by the enormous conferences with main subject the phenomena of climatic changes and social aspects linked to participation and consumption. However, this subject of study is mainly interested both social sciences, agricultural and economics. Organic Agriculture combines tradition, innovation and science to benefit the shared environment and promote fair relationships and a good quality of life for all involved (IFOAM, 2008). The advanced research coming from other fields of biology or economic disciplines, as well as from other social disciplines and from observation of reality, that could enable a more precise definition of sustainable agriculture. Moreover, the sustainable agriculture as organic farming contributes to reduce the ecological footprint minimized, such as fertilizers and pesticides (Schulze, 2009). Significant initial evidence indicates that organic agricultural systems deliver greater ecosystem services and social benefits (Reganold \& Wachter, 2016). In addition, the organic farmers in Italian regions have create a network in order to intensify the challenges of the responsibility and accountability of new technologies. The farmers participation has an important impact on social policies and the satisfaction of landless farmers in relationship with standard of living and quality of life. All these elements are well related with the knowledge, participation, social security, and the production that farmers offer in the market.

\section{Farmers perceptions and economic applications of development and conservation}

Farmers perception is the driving force behind personality characteristics, perceptions, previous learning experience and attitudes. From one hand the consumer chooses organic food because they protect the environment, there are no artificial additives, is a natural production, believe in better quality/taste and less pollution etc. From the other hand the farmers produce organic food because there is less environmental impact, preserve local production and because they think they are doing the right thing etc. The well-being of groups of individuals at various territorial level is considered collectively when it involves the goods and services offered from organic farming (Chase, Decker, \& Lauber, 2004). Farmers as a factor of production, has clearly shown that, the 
expansion of human choices among the economic opportunities has changed with the variety of food available in the markets. Even though the most fundamental one is the gainful employment and the possibility to preserve the environment, biodiversity and the cultural traditions, creating a high income for farmers (Dunlap, 2018). Furthermore, we will analyse the relationships between two groups of farmers active and non-active farmers. The active farms are considered the group of which their activity is constantly, and they meant to provide an income from the activity on agriculture sector. The inactive farms are the farms that spend a total of hours on agriculture activity, but this is not the only activity they have at the same time, so maybe a weekend work for helping on an property that they inherit or a part-time work that they decided to do and they don't meant to provide income even would ideally produce all needed food, year-round. This is becoming increasingly popular mechanism among who wish to live "off the grid" and become more sustainable farms and communities. The number of total farms in Italy in 2013 was decreased by $9.2 \%$ compared to what was reported by the 2010 Agricultural Census (ISTAT, Istituto Nazionale di Statistica, 6 Censimento Agricoltura, 2010). The agricultural area is decrease in the North-West $(-5.7 \%)$ and in the Centre $(-6.3 \%)$, more restrained is in the North-East $(-1.7 \%)$, in the South $(-3,0 \%)$ and in the Islands $(-0.9 \%)$ (ISTAT, Istituto Nazionale di Statistica, 6 Censimento Agricoltura, 2010). During the 2015 the number of organic farmers in Italy is increasing and shows a positive rate during the time. The organic agriculture area with highest values in terms of share is located basically in the following areas: (Puglia, Marche, Calabria and Sicily). In this chart it is prospected the advancement of number of organic farmers in Italy. It is also reflected the fact that organic farming is particularly present in regions with extensive livestock production systems based on permanent grassland. The importance of the organic sector is generally lower in the regions of plains where more intensive production systems prevail (European Commission, Facts and figures on organic agriculture in the European Union, 2016).

\section{$2,500,000$}
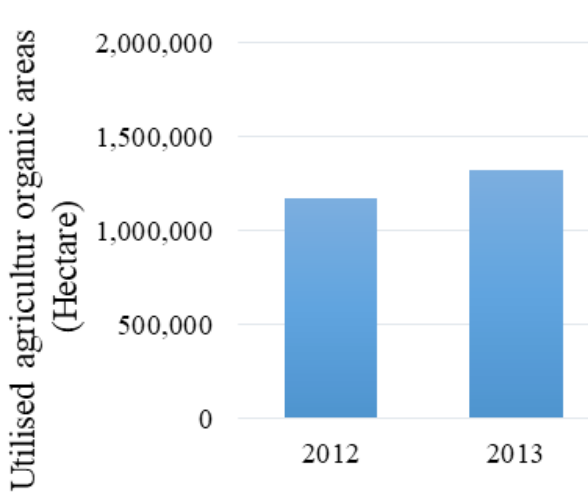

Italy

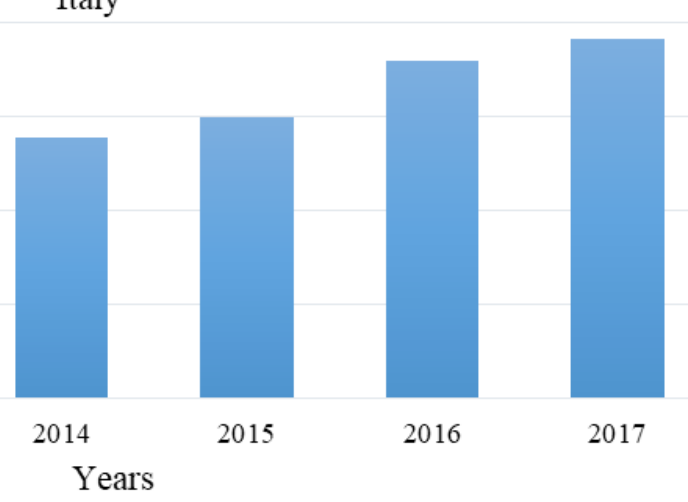

Fig. 1 - Total fully converted and under conversion to organic farming in Italy from 2012 to $2017 .{ }^{1}$

\footnotetext{
${ }^{1}$ Source: Eurostat 2018
} 
This chart includes total full converted and under conversion organic farming in Italian Regions (EUROSTAT, 2018). The number of employees of holder's family is reducing. This is due to the fall in family farms labour, defining as agricultural entrepreneurship which are owned by individuals and followed by the cessation of many small businesses where the number of family labour force exceeds the number of hired workforce. Even though the local and scientific knowledge should be integrated between farmers. The need for scientific information and analysis to inform stakeholder deliberation has been identified by many authors as an essential ingredient in any participatory process (Fischer \& Young, 2007). In this context, the total number of days worked in the company are almost stable (+ $0.8 \%)$, thanks to the significant increase in non-family labour force (+14.3\%). Managing water as an economic asset not only in agriculture sector represents an important way to ensure the efficient use encouraging the conservation and protection of water resource and organic farming. Considering this, it is fundamental to recognise and encourage a more widespread reuse of the resource in agriculture sector and its greater conservation proposed. As possible solution for this application could be applied the principle of "polluter pays" or "consumer pays" in the determination of water services tariffs (domestic, industrial, agriculture) and the connotation of economic good that is assigned to the resource. In this point is needed to consider an economic asset capable of market valuation, to understand the right expectation management and market solutions to resolve inefficiencies in its management. The administration in terms of use and preservation of water and land in agriculture sector is totally in the hand of stakeholders and cultural traditions of farmers (Turner, Davidson-Hunt, \& O'Flaherty, 2003). The law and the directive of Water have been implemented from United Nations at The Dublin Statement on Water and Sustainable Development, 1992, (UNESCO, 1992). Other Assessments and Agreements in international and global level are implemented and adopted for a more sustainable and efficient agriculture production preserving the environment issues including water issue. The Common Agricultural Policy (CAP) is the agricultural policy of the European Union. In fact, (CAP) has been destined to undergo many changes during the time. The last legislative proposal was made $1^{\text {st }}$ June 2018, where European Commission has presented the legislative proposals on the common agricultural policy (CAP) beyond 2020 (EC, 2018). These proposals for a new EU common agricultural policy CAP aim to make more responsive to current future challenges such as climate change or generational renewal in rural development, while continuing to support European farmers for a sustainable and competitive agricultural sector (EC, 2018). The sustainable agricultural was introduced for the first time from McClymont on his book "New Roots for Agriculture", considering farming in sustainable way and a healthy environment, economic profitability, social responsibility and economic equity, (McClymont, 1980). Sustainability generally focuses on the stewardship business process of farmers and practices of principal government actors, rather than a specific agricultural product. 
In this context it is opportunity to introduce the concentration and the attention on the development of the sustainable policies on the process of farms activities and their income perception. One of the most important objectives of the future (CAP) is to ensure a fair income to farmers. The farmers are at the heart of Europe's society and have a very important role on rural communities on providing vital and sustainable public goods (Fuentes, 2010). The contribution and support of farmers in development of rural areas in European Union and specially in Italian reality is helping new generations of farms to join the "old profession", thought mentoring of young farmers by more experienced ones. The tools for achieving those experiences are planned with the succession plans and improving knowledge transfer from one generation to the next. European Union encourage young farmers to improve access to land through more flexible rules on taxation, inheritance and giving financial support for young farmers (Atari, Yiridoe, Smale, \& Duinker, 2009). Thanks to this initiative and the revival of young Italian farmers the number of young farmers it has been considerably increased in Italian regions in the last three years (Coldiretti, 2017). Italy is one of the highest countries in European Union level for the number of young people under 35 in agriculture farms. From a summary of the main results realized from the $6^{\text {th }}$ survey of Agriculture made by ISTAT, it is seen that the number of farms increases from year to year (ISTAT, Istituto Nazionale di Statistica, 2019). About $99 \%$ of farms operate on family labour and $30.7 \%$ of the company leaders are female. The total number of farmers in Italy is 1,620,884 and the distribution in age is mixed. The amount number of Italian agricultural organic enterprises is $\mathbf{5 7 . 6 2 1}$ in 2018 . Regarding the groups of age of farmers, we decided to put together in a large group of farmers into the same cluster (35-65 years old), representing in this term the recreationally and multifunctionality of so called newold-farmers or "age of farming" (Miftari \& Musaraj, 2019). The age of farmers is important for the distribution of subsidies that the regions permit and finance principally for the young farmers and the others. This is a very important indicator present in different regional contexts and applications. In this matter farmers and the local government in agriculture sector is the main actor for the progress of policies and sustainable development. 


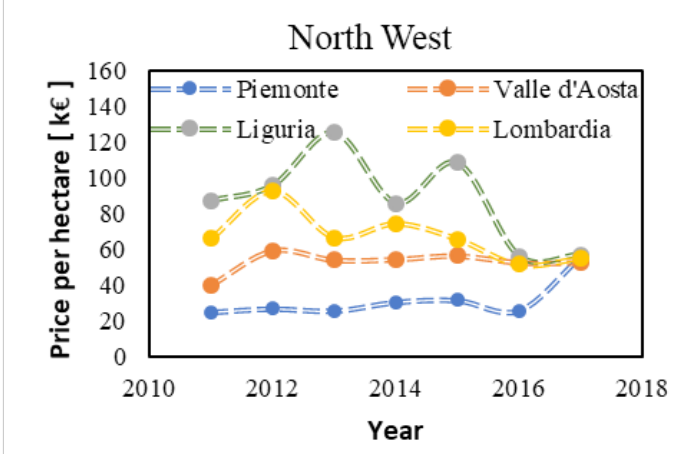

Centre

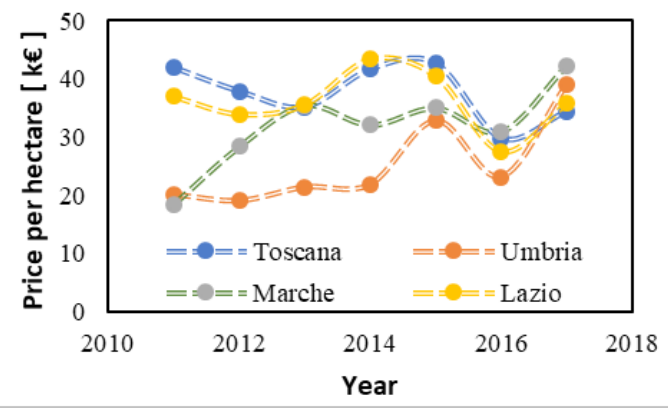

Islands

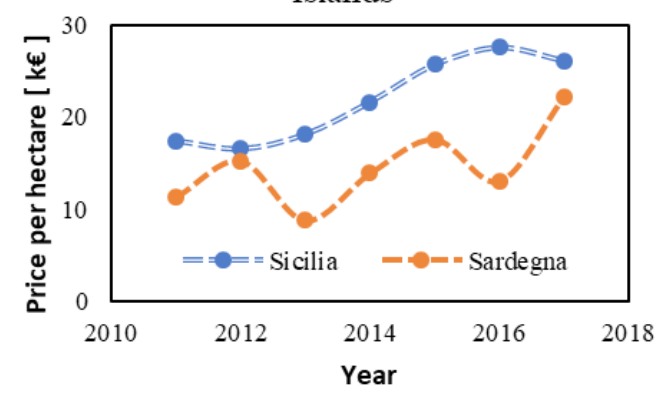

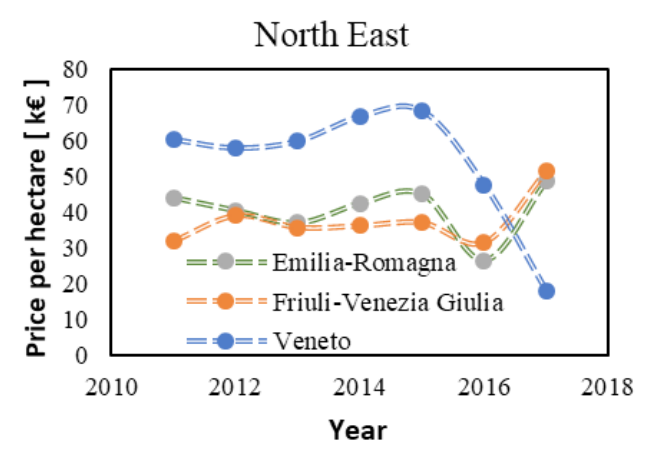
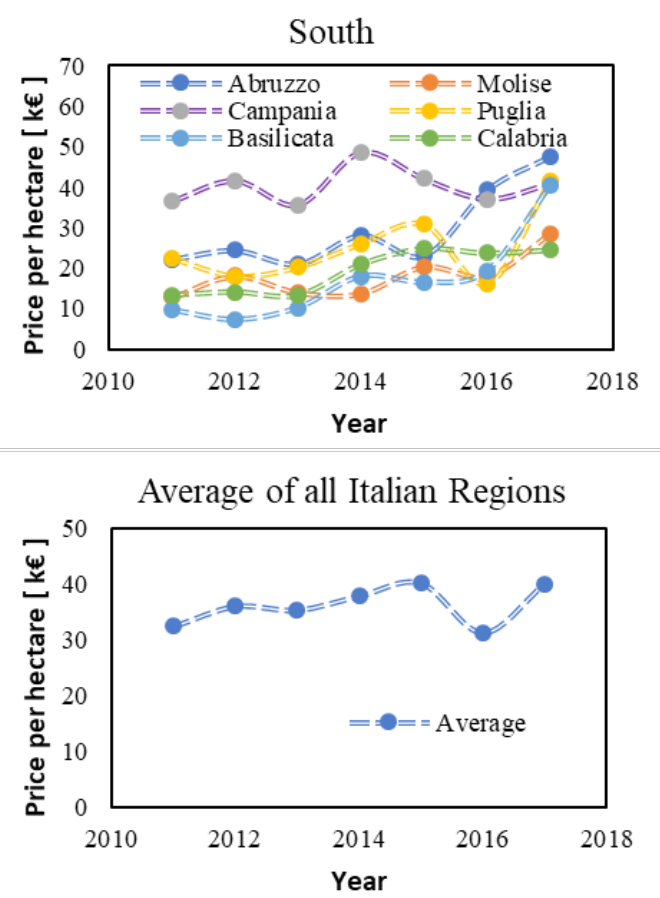

Fig. 1 - Agricultural land prices by region (unit Euro per hectare/arable land), from 2010 to $2017 .^{2}$

The charts below show the agriculture economic trend of the average price of arable land from 2010 to 2018. This chart is a panoramic imagine showing how the price in euro per hectare have been changing during the years that we are considering. Furthermore, the charters show the non-linear price line for Liguria, Veneto and Abruzzo. The trend of prices for Liguria and Veneto regions have been decrease in terms of price per hectare for arable land from 2015. Specially Abruzzo has undergone an increase of price per hectare for arable land from 2015. Moreover, the oscillations in terms of agriculture surplus has reminded stable over time for the most Italian Regions, there has been a strong growth in agriculture trade surplus in 2017 in most regions. The 
average of price unit per euro is 36.273 per hectare in the last 7 years calculations and elaborations (EUROSTAT, 2018). Italian Regions have an extremely diversification on the distribution of economic growth, economy extension and perception of income. The perception of agriculture income generated and determined from different limits, of the land owned, which are the economic activities taxed according to the calculations of this method.

\section{Alternative of farmers between Organic Agriculture versus Conventional Agriculture}

The definition of organic farming is a friendly farming system that has been existing from the ancient period of living and food production from farmers around the world. The conventional agriculture farming has been developed mostly when the demand for food started to increase as consequence of population growth. It is led to significant increase in production, as a consequence of using very productive inputs (seeds, hybrids, etc.) and also genetically modified organisms, together with a larger mechanization of processes and large-scale usage of water pipe-lines, fertilizers, pesticides and bio-stimulators (Stoian \& Caprita, 2019). The social sciences are one means through which researchers and practitioners can come to understand the human dimensions of conservation and natural resource management (Bennett, et al., 2017). The transformation is much more profound than simply tweaking the existing industrial agricultural system. Conversion to organic agriculture production is most defined through regulations adopted by the Council Regulations (EC) No 834/2007 of June 2007. On organic production and labelling of organic agriculture products and repealing Regulation (EEC) No. 2092/91 (European Commission, Regolamento (CE) nr. 834/2007 del Consiglio, 2007), defines organic production as "an overall system of farm management and food production that combines best environmental practices, a high level of biodiversity, the preservation of natural resources, the application of high animal welfare standards and a production method in line with the preference of certain consumers for products produced using natural substances and processes". It involves a given time spam as well as specific constraints and procedures, whereby organic principles must be applied to parcels and animals for more than three years (Lamine \& Bellon, 2009). The IFOAM definition for organic agriculture combines tradition, innovation and science to benefit the share environment and promote fair relationships and a good quality of life for all involved (IFOAM, 2008). According to Food and Agriculture Organization of the United Nations defines, in "Codex Alimentarius Commission", defines organic agriculture as a "holistic production management system which promotes and enhances agroecosystem health, including biodiversity, biological cycles, and soil biological activity" (FAO, 1999). The). Other authors define organic farming as a system which avoids or largely excludes the use of synthetic inputs (such as fertilizers, pesticides, hormones, feed additives etc.) and the maximum extent feasible rely upon crop rotations, crop residues, animal manures, off-farm organic waste, mineral grade rock additives and 
biological system of nutriment mobilisation and plant protection" (Gold, 2007). Organic agriculture is based on minimize energy use, minimize pesticide residues, minimize water pollution, minimize total costs protect biodiversity, ecosystem services, soil quality, nutritional quality, employment of workers, yield etc. Even organic farming system produce lower yields compared with conventional agriculture they are more profitable and environmentally friendly and deliver equally or more nutritious foods that contain less (or no) pesticide residue, compared with conventional farming. Moreover, initial evidence indicates that organic agriculture systems deliver greater ecosystem services and social benefits. Significant barriers exist to adopting these systems, however, and a diversity of policy instruments will be required to facilitate their development and implementation (Reganold \& Wachter, 2016). However, the new technologies application can make organic agriculture more profitable for the farmer. But high costs to adapt technology for individual farmers can be significant adoption hurdles, especially in case of limited knowledge and skills (Waltera, Fingerb, Huberb, \& Buchmanna, 2017). From the social movements rural sociologists can learn to look food in a new way, as something whose meaning and value is not exhausted by its nutritional content, its economic cost or the political agreements underpinning its production, but which is, as Fiddes says (Fiddes, 1991), "part of our way of life" (Tovey, 1997). With the process of selecting our food which has been produced with different standards and different locations, in a vertical way we are reproducing particular social interactions and structures to not leave without weight the moral and cognitive ideas of process of production to every single farmer. Farmers who adopt organic farming aspires to produce food which is not only 'good to eat' but also 'good to think' (Beardsworth \& Keil, 1992) - and in doing so, also to produce and construct a certain kind of society. So, farmers are a kind of social movement who guarantees food production systems and consumption habits and examine how the protection of environment is handled in all the societies, regulations, by state development agencies and by farmers.

\section{Conclusions}

In this paper emphasizes the importance of studies in sociology of agriculture as part of sociology of organisation and economic process; sociology of work and about food production and consumption. In rural sociology the human dimension develops the argument of transformation towards the agriculture sustainability and requires social, economic and environment changes. Social movement and social learning of this group of society become relevant on promoting important decision making based on knowledge and adoption on human-technology-environment. All thesetransformations come out when farmers started to know that organic sector is driven to largely by high income earns than their conventional counterparts and attracted both to the perceived health and food safety attributes. From our work we can show the number 
of organic farmers is increasing in Italian regions focusing how local social contexts and networks are influencing the choices of farmers related to the environment. Other results obtained from this article regarding the age of farming are shown. Improving sustainable agriculture in social society the group of farmers age from 35 to 65 are the most active in applying organic farming. This phenomenon happens not only for the simplified system on adoption and production but even for all the other constraints can encounter during the transformation and certification process and application on their own farm. The importance of local social context and the production together with the conservation of traditional food applying organic system is the main network and applied knowledge in a daily life behaviour of collective farmers. Altogether, it is clear to say that direct consumers and markets need to take into account possible organic agriculture scenarios and their effects on climatic change and environment. This scenario shows the weakness of organic farming that could be one of the diseases for the security of the production. The social and collaborative associated as NaturaSì and Slow Food in Italy in cases of bad season or natural disease reimburse the farmers the production from natural factors lost. Of course, this application and collaboration is strictly followed by the pertinent authorities.

\section{Bibliography}

1. Atari, Odwa., Yiridoe, Emmanuel., Smale, Shawn., \& Duinker, Peter. (2009). What motivates farmers to participate in the Nova Scotia environmental farm plan program? Evidence and environmental policy implications. Journal Environment Management, 90, 1269-1279.

2. Beardsworth, Alan., \& Keil, Teresa. (1992). The vegetarian option: varieties, conversions, motives and careers. Sociological Review 40 (2): 253-292.

3. Bennett, Nathan., Roth, Robin., Klain, Sarah., Chan, Kai., Christie, Patrick and Clark, Douglas A. (2017). Conservation social science: Understanding and integrating human dimensions to improve conservation. Biological Conservation 205: 93-108.

4. Best, Henning. (2009). Organic farming as a rational choice: empirical investigations in environmental decision making. Rationality and Society, 21, 197-224.

5. Burton, Rob. (2006). An alternative for farmer age as an indicator of life-cycle stage: the case for a farm family age index. Journal of Rural Studies, 22 (4): 485492.

6. Chase, Lisa, C., Decker, Daniel, J and Lauber, Bruce, T. (2004). Public Participation in Wildlife Management: What Do Stakeholders Want? Society \& Natural Resources 17 (7): 629-639. 
7. Chirkov, Valery. (2009). A Cross-Cultural Analysis of Autonomy in Education: A Self-Determination Theory Perspective. Theory and Research in Education 7 (2): 253-262.

8. Coldiretti. (2017). Aumento degli finanziamenti Europei per i giovani. Fonte: https://giovanimpresa.coldiretti.it/: https://giovanimpresa.coldiretti.it/

9. Daci, J. (2012). Protection of the Human Right to Water Under International Law-The Need for a New Legal Framework. Academicus International Scientific Journal, 3(06), 71-77.

10. De Rosa, Marcello., Bartoli, Luca and Chiappini, Silvia. (2013). The Adoption of Agricultural Extension Policies in the Italian Farms. New Medit, 20-27.

11. Dunlap, Riley. (2018). Environmental Sociology. Companion to Environmental Studies (6): 315-320.

12. European Commission. (2018). European Commission: Future of the common agricultural policy. Fonte: Future of the common agricultural policy: https:// ec.europa.eu/info/food-farming-fisheries/key-policies/common-agriculturalpolicy/future-cap_en

13. European Commission. (2007). Regolamento (CE) nr. 834/2007 del Consiglio. Fonte: Gazzetta ufficiale dell'Unione europea: https://eur-lex.europa.eu/legalcontent/IT/TXT/PDF/?uri=CELEX:32007R0834\&from=FR

14. European Commission. (2016). Facts and figures on organic agriculture in the European Union. Fonte: Agriculture and Rural Development: https://ec.europa. eu/agriculture/rica/pdf/Organic_2016_web_new.pdf

15. EUROSTAT. (2018). European statistics. Fonte: Eurostat Database: https:// ec.europa.eu/eurostat/data/database

16. FAO. (1999). Food and Agriculture Organization of the United Nations. Fonte: Organic Agriculture: http://www.fao.org/organicag/oa-faq/oa-faq1/en/?fb_ locale $=\mathrm{fr} \_\mathrm{fr}$

17. Fiddes, Nick. (1991). Meat: a natural symbol (London: Routledge and Kegan Paul). London: Routledge.

18. Fischer, Aanke and Young, Juliette. (2007). Understanding mental constructs of biodiversity: Implications for biodiversity management and conservation. Biological Conservation 136: 271-282.

19. Fuentes, José-Maria., Gallego, Eutiquo., García, Antonio and Ayuga, Francisco. (2010). New uses for old traditional farm buildings: the case of the underground wine cellars in Spain. Land use policy, 27 (3): 738-748.

20. Gold, Mary. (2007). Organic Production and Organic Food: Information Access Tools. U.S. Department of Agriculture (USAD), 01-20. Fonte: United States Department of Agriculture (USDA). 
21. Hoffmann, Alessandro. (2009). Il modello delle Politiche agricole. FrancoAngeli.

22. IFOAM. (2008). International Federation of Organic Agriculture Movements. Fonte: IFOAM Organic Agriculture: https://www.ifoam.bio/en/organiclandmarks/definition-organic-agriculture

23. ISTAT. (2010). Istituto Nazionale di Statistica, 6 Censimento Agricoltura. Italia: Istituto Nazionale di Statistica. https://www.istat.it/

24. ISTAT. (2019). Istituto Nazionale di Statistica. Fonte: Istituto Nazionale di Statistica: https://www.istat.it/: https://www.istat.it/

25. Lamine, Claire and Bellon, Stephane. (2009). Conversion to organic farming: a multidimensional research object at the crossroads of agricultural and social sciences. A review. Agronomy for Sustainable Development 29: 97-112.

26. Lockie, Steward. (2002). "Eating Green": Motivations Behind Organic Food Consumption in Australia. Sociologia Ruralis 42 (1): , 23-40.

27. Malthus, Thomas. (1798). An Essay on the Principle of Population, as it Affects the Future Improvement of Society with Remarks on the Speculations of Mr. Godwin, M. Condorcet, and Other Writers. London: Printed for J. Johnson, in St. Paul's Church-Yard.

28. McClymont, Gordon. (1980). New Roots for Agriculture.

29. Miftari, Alda. (2019). Sustainability of water use in agriculture. Southern European farmers participation and social impact. Academicus International Scientific Journal 19: 131-145.

30. Miftari, Alda and Musaraj, Arta. (2019). Sustainable Rural Development and the Effects of Education, Demography and Access in Agricultural Sector Structure and Efficiency. CBU International Conference Proceedings (7), 7.

31. Moini, Giulio. (2012). Teoria critica della partecipazione. Un approccio sociologico. Roma: Franco Angeli.

32. Reganold, John and Wachter, Jonathan. M. (2016). Organic agriculture in the twenty-first century. Nature Plants 2 (2): 1-8.

33. Schulze, Detlef Ernest and Freibauer, Annette. (2009). Importance of methane and nitrous oxide for Europe's terrestrial greenhouse-gas balance. Nature geoscience, 841-851.

34. Stoian, Mirela and Caprita, D. (2019). Organic agriculture: Opportunities and Trend. In Agri Food Economics and Sustainable Development in Contemporary Society. IGI Global: Hershey, PA, USA 23: 275-293.

35. Stolze, Matthias., Piorr, Annette., Haring, Anna and Dabbert, Stephan. (2000). The Environmental Impacts of Organic Farming in Europe. Organic Farming in Europe, 50. 
36. Tovey, Hilary. (1997). Food, Environmentalism and Rural Sociology: On the Organic Farming Movement in Ireland. Sociologia Ruralis 37 (1): 21-37.

37. Turner, Nancy., Davidson-Hunt, lain and O'Flaherty, Michael. (2003). Living on the edge: ecological and cultural edges as sources of diversity for socialecological resilience. Human Ecology 31: 439- 461.

38. UNESCO. (1992). The Dublin Statement on Water and Sustainable Development. Fonte: http://www.wmo.int/pages/prog/hwrp/documents/english/icwedece. html

39. Zeneli, F. (2016). Analysis of risks and investments' opportunities in water sector. Academicus International Scientific Journal, 7(13), 128-137.

40. Waltera, Achim., Fingerb, Robert., Huberb, Robert and Buchmanna, Nina. (2017). Smart farming is key to developing sustainable agriculture. PNAS 114 (24): 6148-6150. 